\title{
Georgia (Republic)
}

National Cancer Institute

\section{Source}

National Cancer Institute. Georgia (Republic). NCI Thesaurus. Code C16634.

A country in southwestern Asia, bordering the Black Sea, between Turkey and Russia. 